УДК 94(470.6).084.8

Н. Д. Судавцов

\title{
БИТВА ЗА КАВКАЗ В ИСТОРИЧЕСКИХ СУДЬБАХ НАРОДОВ РЕГИОНА
}

В статье рассматривается противостояние народов СССР, Красной армии войскам фашистской Германии и её союзников в сражениях за Кавказ в годы Великой Отечественной войны, проявленные при этом мужество и массовый героизм советских людей в борьбе с общим врагом в самой продолжительной битве Второй мировой войны. Руководство Германии ставило перед войсками, наступавшими на Кавказ, задачу прорваться в Закавказье по побережью Чёрного и Каспийского морей, через Кавказские перевалы. Имелось в виду захватить продовольственные районы Северного Кавказа, нефтепромыслы Кубани, Грозного, Баку, обеспечив таким образом топливом свои вооружённые силы и лишив его советские войска. Одновременно расчёт был на то, чтобы оказать давление на Турцию с целью её вступления в войну против СССР, а также угрожать Среднему Востоку и через Иран, Афрганистан прорваться в Индию, колонию Британской империи. Исследование показало, германское командование не дооценило возможности СССР и переоценило собственные силы, что привело не только к поражению на Кавказе, но и в целом в войне против СССР.

Ключевые слова: война, армия, флот, оборона, наступление, Кавказ, Сталинград, партизаны, горы, авиация, оккупация.

N. D. Sudavtsov

\section{BATTLE FOR THE CAUCASUS IN THE HISTORICAL FATE OF THE PEOPLES OF THE REGION}

The article studies the opposition of the people of the USSR and the Red Army to the troops of fascist Germany and its allies in battles for the Caucasus in days of the Great Patriotic War. It shows courage and mass heroism of the Soviet people in fight against the general enemy in the longest fight of World War II. The leadership of Germany put before the troops attacking the Caucasus a task to break in Transcaucasia on the coast of the Black and Caspian seas, through the Caucasian passes. It was supposed to occupy food areas of the North Caucasus, oil fields in Kuban, Grozny and Baku, thus providing the armed forces with fuel and depriving the Soviet troops of it.

5 лет назад с 25 июля 1942 г. по 9 октября 1943 г. шло одно из крупнейших и самых продолжительных сражений Второй мировой войны - битва за Кавказ на фронте протяжённостью в 1000 километров по кавказским предгорьям, реке Терек от Чёрного и почти до Каспийского морей. Она проходила одновременно с эпохальными сражениями за Сталинград до фревраля 1943 г., а в июле - августе на Курской дуге.

О битве за Кавказ написаны и изданы тысячи статей, сотни монографий, воспоминаний в нашей стране и за рубежом. В них содержатся
At the same time they planned to put pressure upon Turkey for the purpose of her introduction in war against the USSR and also to threaten the Middle East and through Iran, Afghanistan to break to India, the colony of the British Empire. The research shows that the German command underestimated the power of the USSR and overestimated its own forces that led not only to defeat in the Caucasus, but also in the war against the USSR.

Key words: war, army, fleet, defense, approach, Caucasus, Stalingrad, guerrillas, mountains, aircraft, occupation.

различные точки зрения в отображении битвы за Кавказ и её оценке. Однако, при всей противоречивости оценок остаётся неизменным признание того, что битва за Кавказ сыграла важную роль в разгроме фашистской Германии и её сателлитов $[1 ; 2 ; 3 ; 7 ; 11 ; 13 ; 14 ; 17 ; 18 ; 19 ; 25$; 27]. Но сама по себе эта тема неисчерпаема, поскольку в то время решалась судьба не только Советского государства, но и мировой истории. В ходе битвы за Кавказ проявились небывалое мужество, героизм, единение народов СССР в борьбе с общим врагом, что пытаются часто пытаются опровергнуть и оспорить в наши дни. 
Как известно, руководство фрашистской Германии, начиная 22 июня 1941 г. войну против СССР, делало ставку на своё военное превосходство, многонациональный состав населения советского государства, рассчитывая на то, что, как только германские войска вторгнутся на территорию Советского Союза, между народами, населяющими его, начнется вражда и советское государство развалится. В инструкциях германского командования указывалось, как следует действовать: «В Прибалтийских странах германским органам опираться на немцев; использовать в интересах Германии противоречия между литовцами, латышами и русскими. На юге использовать в наших интересах возможное наличие противоречий между украинцами и великороссами, на Кавказе между туземцами - грузинами, армянами, татарами и русскими» [4, с. 252].

Однако эти надежды фрашистского руководства не оправдались. Народы СССР во время смертельной опасности, нависшей над страной, сплотились для отпора врагу, проявляя мужество, героизм и единение на фронте и в тылу. Это ярко проявилось в период битвы за Кавказ.

Германское командование, потерпев поражение под Москвой, летом 1942 г. решило нанести главный удар по советским войскам на южном направлении на Сталинград и Кавказ. Это было связано не только с его геополитическим положением, но и в значительной мере с тем, что Германия очень нуждалась в кавказской нефти. По словам фельдмаршала Паулюса, Гитлер по этому поводу на совещании в штабе группы армий «Юг» 1 июня 1942 г. в г. Полтаве заявил: «Моя основная мысль занять область Кавказа, возможно, основательнее разбив русские силы... Если я не получу нефть Майкопа и Грозного, я должен ликвидировать войну...» [23, с. 26]

Для этого было создано две группы армий: «А» для наступления на Кавказ и «Б» для наступления на Сталинград. В директиве Гитлера от 23 июля ставилась задача главными силами группы «А» нанести удар на Северный Кавказ «...группировка, имеющая в своем составе главным образом танковые и моторизованные соединения, выделив часть сил для обеспечения фрланга и выдвинув их в восточном направлении, должна захватить район Грозного и частью сил перерезать Военно-Осетинскую и Военно-Грузинскую дороги по возможности на перевалах. В заключение ударом вдоль Каспийского моря овладеть районом Баку. Группе армий «А» будет передан итальянский альпийский корпус. Для этих операций группы армий «А» вводится кодированное название «Эдельвейс» [12, с. 326]. Уверенность германского командования в успехе вселило тяжёлое поражение, которое потерпела Красная Армия под Харьковом в мае 1942 г.

Немецкие войска, разделенные на две группы, значительно превосходили советские войска в танках, авиации. Для наступления на Северный Кавказ в группу «А» были включены 17 полевая, 1-я и 4-я танковые, которая вскоре была переброшена на Сталинградское направление, 3-я румынская армии, 4-й воздушный фолот. В их составе было 13 пехотных, 5 танковых, 4 моторизованные, 3 кавалерийские дивизии до I тыс. самолетов. Им противостояли войска Южного и часть сил Северо-Кавказского фронтов, уступая противнику в людях в 1,5, в орудиях и минометах в 2, в танках более чем в 9 и в авиации почти в 8 раз. [14, с. 455]. Выполняя директиву, немецкие войска приступили к осуществлению операции. Враг устремился через Дон в направлении на Сталинград и Кавказ. Был взят город Ростов. Операция «Эдельвейс» по захвату Кавказа началась 25 июля 1942 г. превратившись в самую продолжительную битву в истории Второй мировой войны, длившуюся 442 дня.

Преследовалось несколько целей: захватить богатства Кавказа и, прежде всего, кубанскую, грозненскую, бакинскую нефть, продовольствие, понудить Турцию вступить в войну на стороне Германии, уничтожить Черноморский флот, лишив его баз на побережье Чёрного моря, а также угрожать Среднему Востоку и жемчужине Британской империи Индии.

Рейхсминистр Германии по делам восточных территорий А. Розенберг в своей записке «О преобразовании Кавказа», составленной в это время, писал: «Интересы Германии заключаются в том, чтобы создать прочные позиции на всем Кавказе и тем самым обеспечить безопасность континентальной Европы, т.е. обеспечить себе связь с Ближним Востоком. Только эта связь с нефтяными источниками может сделать Германию и всю Европу независимыми от любой коалиции морских держав в будущем. Цель германской политики - господство над Кавказом и над граничащими с юга странами как в политическом, так и в военном отношении» [14, с. 455].

Поскольку сплошной линии фронта на юге не было, германское командование, используя преимущество в танковых, моторизованных войсках и авиации, не имея серьёзных естественных преград, приступило к реализации 
своих планов. Двинувшись на Северный Кавказ и развивая наступление, немецкие соединения обходили советские войска, часто не давая им возможности закрепиться на удобных оборонительных рубежах.

Значительно уступая противнику, особенно в техническом оснащении, а также из-за просчётов командования, советские войска отступали на юг. Над страной нависла смертельная опасность.

В создавшейся ситуации 28 июля народным комиссаром обороны И. Сталиным был издан приказ №227, известный как «Ни шагу назад». B нём давалась жёсткая оценка сложившемуся положению: «Отныне железным законом дисциплины для каждого командира, красноармейца, политработника должно явиться требование - ни шагу назад без приказа высшего командования. Командиры роты, батальона, полка, дивизии, соответствующие комиссары и политработники, отступающие с боевой позиции без приказа свыше, являются предателями Родины. С такими командирами и политработниками и поступать надо как с предателями Родины. Таков призыв нашей Родины. Выполнить этот приказ - значит отстоять нашу землю, спасти Родину, истребить и победить ненавистного врага» [24, с. 75-77].

Приказ был прочитан во всех воинских подразделениях. В соответствии с ним были созданы штрафные батальоны, роты, заградительные отряды. Это имело большое значение для повышения уровня ответственности кадров всех уровней, личного состава за положение дел в воинских частях, поднятия боевого духа в войсках на отпор врагу.

Советским войскам под напором противника пришлось отступать с тяжёлыми боями по открытой степной местности, подвергаясь постоянным атакам немецкой авиации, танковых соединений. Воинским соединениям не удалось даже закрепиться на оборонительных рубежах, построенных осенью 1941 года изза сильного натиска врага и опасности быть окружёнными, в связи с обходными манёврами танковых и моторизованных соединений противника. Имея преимущество в подвижности, они часто упреждали советские войска в занятии выгодных оборонительных рубежей. Поредевшим воинским соединениям Красной Армии пришлось с тяжёлыми боями отступать до естественных преград в предгорьях Кавказа, реки Терек, где по приказу Ставки готовилась глубокоэшелонированная оборона.

В этих условиях для лучшего управления войсками в противостоянии противнику совет- ским командованием были созданы две оперативные группы: Донская (51-я, 37-я, 12-я и 4-я воздушная армии), которая прикрывала Ворошиловское (ставропольское) направление, Приморская, созданная из преобразованного Северо-Кавказского фрронта (18, 56, 47 армии, 1-й отдельный стрелковый и 17 кавалерийский корпуса), обороняла краснодарское направление и Таманский полуостров [3, с. 40-41].

На Западе внимательно следили за положением дел на Юге СССР. Успешное наступление германских войск на Сталинград и Кавказ вызывало там серьёзные опасения. Созданный в Англии Комитет обороны Среднего Востока в июле 1942 г., явно не дооценивая действия советских войск, пришёл к выводу, что немцы вероятно к 10 сентября прорвутся через Кавказ в Сирию и Ирак, а к 15 октября в Северный Иран, что угрожало интересам Великобритании на Среднем Востоке и в Индии [8, с. 6]. В связи с этим премьер - министр Великобритании У. Черчилль в августе даже прилетел в Москву. Во время встречи с И. Сталиным он просил его остановить немцев. На это Верховный Главнокомандующий вооружёнными силами СССР уверенно ответил, что немецкие войска будут остановлены в горах [5, с. 171-172].

Между тем германские войска продолжали наступление на Сталинград и Кавказ, испытывая острую нехватку топлива в немецких соединениях. В связи с этим приходилось даже останавливать в походе танки. Так, в 40 танковом корпусе с самого начала наступления, по словам немецкого автора В. Тике, «... трудности со снабжением были особенно заметны: недостаток горючего через несколько дней стал хроническим. Часто приходилось собирать все остатки горючего, чтобы могла продолжить марш хотя бы одна танковая дивизия. По этой причине слово «нефть» стало волшебным, приводившим дивизии в движение. Под Майкопом и Грозным они надеялись найти достаточно горючего» [25, с. 53].

Первый секретарь Ставропольского крайкома ВКП(б) М. Суслов докладывал секретарю ВКП (б) Андрееву: «Части немецкой армии появились на территории Орджоникидзевского края 2 августа в Молотовском районе. В этот же день немецкими войсками полностью было прекращено движение по Ворошиловской железной дороге. Продвижение войск противника почти не встречало сопротивления со стороны частей Красной Армии, в беспорядке по всей территории края. Это обстоятельство дало немцам возможность быстро занимать города и районы края, а отсутствие разведок о продви- 
жении врага делало его появление во многих случаях совершенно неожиданным» [6, Л. 33].

В сложившейся ситуации советское командование приняло решение отвести войска в предгорья Кавказа, там остановить противника, измотать его и, накопив резервы, разгромить. В середине августа германские войска вышли к реке Терек, предгорьям Кавказа, на перевалы Главного Кавказского хребта. Но им не удалось решить главную задачу: окружить и разгромить советские войска на Северном Кавказе, которые закрепились на оборонительных рубежах. Там и развернулись тяжёлые оборонительные бои. Германские войска прилагали огромные усилия к тому, чтобы как можно быстрее сломить сопротивление Красной Армии, и прорваться к Грозному и Баку, захватить Новороссийск, вступить в Закавказье через перевалы, по каспийскому и черноморскому побережью.

Народы Северного Кавказа и Закавказья в период смертельной опасности для страны единодушно заявили о своей решимости защищать Кавказ. Это было продемонстрировано на многочисленных митингах. 13 августа 1942 г. во Владикавказе у братской могилы солдат революции состоялся многотысячный митинг представителей Дона, Кубани, Ставрополья, Кабардино - Балкарии, Северной Осетии, Чечено-Ингушетии и Дагестана. Его участники, выражая волю народов Северного Кавказа, поклялись отдать все силы на разгром врага. В обращении «Ко всем народам Северного Кавказа» говорилось словами К. Хетагурова, что «лучше умереть народом свободным, чем кровавым потом рабами деспоту служить». 23 августа 1942 г. участники антифашистского митинга, состоявшегося в Тбилиси, обращаясь к народам Закавказья писали: «Мы превратим в неприступные рубежи каждую горную тропу, каждое ущелье, где врага всюду будет подстерегать неминуемая смерть» [4, с. 14].

Это способствовало тому, что на Северном Кавказе и в Закавказье в кратчайшие сроки было сформировано 10 национальных дивизий и других воинских формирований, которые приняли непосредственное участие в боевых действиях по защите Кавказа, а затем и в разгроме фашистской Германии.

А поскольку немецкие войска по степной части Северного Кавказа продвигались довольно быстро, местными органами не было проведено необходимых мероприятий по организации эвакуации населения, материальных ценностей, так как такого оборота дела никто не ожидал, а также из-за слабо развитой транспортной системы, многое не удалось вывез- ти. Поэтому пришлось уничтожать, приводить в негодность промышленное оборудование, сельскохозяйственную технику, чтобы не достались врагу и не работали на него.

Нефтепромыслы на Кубани германское командование запретило бомбить, рассчитывая захватить их невредимыми и немедленно приступить к добыче так необходимой нефти. Однако, из этого ничего не вышло, так как отступающие советские воинские части вместе с промысловиками привели их в негодность в районе г. Майкопа. Так что для получения нефти необходимо было восстановить её добычу. На это, по расчётам специалистов, которые двигались вместе с германскими войсками, чтобы сразу приступить к добыче нефти, на восстановление скважин требовалось 5-6 месяцев, в то время как она нужна была немедленно. Надежда оставалась на нефтепромыслы Грозного и Баку. Но их ещё нужно было захватить.

В создавшихся условиях это выглядело весьма реальным и очень беспокоило Запад. В Великобритании даже вынашивали планы по вводу в Закавказье своих войск, чтобы не допустить захвата германскими войсками Баку, так как это значительно бы усилило мощь моторизованной германской армии и создало реальную угрозу её вторжения на Средний Восток.

В предгорьях германские войска столкнулись с всё возраставшим сопротивлением советских войск, которые получили значительные подкрепления за счёт формирования национальных воинских частей в Азербайджане, Грузии, Армении, в регионах Северного Кавказа, переброски войск из глубины страны. Значительно улучшалось их материально-техническое снабжение, обеспечение оружием, боеприпасами. На оккупированной территории разворачивалось партизанское движение. Темпы наступления немецко-фашистских войск резко упали, они несли всё возрастающие потери.

Bсе попытки германских войск прорваться к грозненской и бакинской нефти, а также через перевалы и по черноморскому побережью в Закавказье оказались тщетными, хотя они были лучше подготовлены к ведению боевых действий в горах. Для этого имелся 49-й горно-стрелковый корпус, обеспеченный специальным снаряжением, вооружением для ведения боевых действий в горах, личный состав которого прошел подготовку для боевых действий в горных условиях. Многие офицеры корпуса знали Главный Кавказский хребет, который в качестве альпинистов в довоенное время исходили вдоль и поперёк [16, с. 180-181].

На Северном Кавказе по всей линии фронта от Чёрного моря по предгорьям, левобережью 
реки Терек развернулись тяжёлые бои, в которых обе стороны несли значительные потери. Чтобы улучшить оперативное руководство войсками, советское командование подчинило Северную и Черноморскую группы войск Закавказскому фронту. Одновременно шёл процесс накопления резервов для решительного удара по германским войскам на Северном Кавказе за счёт создания новых воинских соединений, выдвижения войск из внутренних районов страны, которые поступали в распоряжение Закавказского фронта, возрастающих поставок вооружения, боеприпасов, снаряжения. Только с 6 августа по 27 сентября Ставка Верховного Главнокомандования усилила Закавказский фрронт 10 и 11 гвардейскими стрелковыми корпусами, 11 отдельными стрелковыми бригадами [13, с. 99].

Тем временем войска Германии и её союзников стали ощущать всё более острый недостаток сил для решительного удара под Сталинградом и на Северном Кавказе. Но в условиях тяжёлых боёв на этих направлениях германское командование было лишено свободного манёвра войсками, так как не могло без ущерба оголить ни то, ни другое направление.

Периодически дискутируется вопрос: а была ли борьба с оккупантами на Северном Кавказе, партизаны. Некоторые авторы отрицают наличие партизанского движения в регионе. А вместе с этим отрицают либо значительно приуменьшают борьбу населения с оккупантами, преувеличивая значение коллаборационизма, который был, но не в таких размерах, как его иногда пытаются представить.

Действительно, на Северном Кавказе не было того размаха партизанского движения, как в Белоруссии, на Украине, Брянщине, где имелись мощные лесные массивы, являвшиеся хорошим укрытием для партизан. Значительная часть территории Северного Кавказа представляла собой безлесную степь. Следует учитывать и то, что на большей части территории региона оккупация продолжалась 4-6 месяцев. Определённое значение имело и то, что оккупанты на первых порах массово не проявили своёй жестокости по отношению к населению. На Северном Кавказе, учитывая его многонациональный состав, наличие казачества, недовольных советской властью, они вели политику заигрывания с населением, пытаясь привлечь его на свою сторону. Массовые расстрелы населения, как правило, проводились тайно. Но при этом составлялись списки очерёдности уничтожения советских людей. Тем не менее, на Северном Кавказе действо- вало 179 партизанских отрядов численностью более 11 тыс. человек, в том числе на Кубани 86 партизанских отрядов, Ставрополье - 40, Кабардино-Балкарии 14, Северной Осетии 11, Чечено-Ингушетии - 28 [17, с. 222]. Руководил партизанским движением Южный штаб партизанского движения, созданный 3 августа 1942 г. по решению Государственного комитета обороны при военном совете Северо-Кавказского фрронта.

На Северном Кавказе основной формой борьбы населения с оккупантами был массовый бойкот мероприятий, которые они проводили. Это нашло своё яркое выражение в том, что были сорваны уборка урожая, осенне-полевые работы. На предприятиях так и не был налажен выпуск основных видов продукции. И это при том, что приказы немецкого командования, комендантов заканчивались фразой: «За невыполнение расстрел». Несмотря на это, советские патриоты, имитируя работу, часто рискуя жизнью, под различными предлогами саботировали мероприятия оккупантов. Это был массовый подвиг советских людей в борьбе с врагом, которые не склонили покорно перед ним головы.

Оккупанты пришли на Северный Кавказ как хозяева. Они не спешили ликвидировать коллективные хозяйства и наделять крестьян землёй, отделываясь обещаниями. Колхозы, были сохранены и переименованы в общины под номерами, а совхозы в госхозы, что давало оккупантам возможность грабить общественное достояние, практически не вторгаясь в индивидуальный сектор. Это оставлялось на потом после того, когда в общественном секторе ничего не останется.

Немцам удалось в августе захватить перевалы Главного Кавказского хребта Клухорский, Марухский, Нахар, Санчаро и др. Это явилось следствием того, что их оборона была организовано плохо. Командующий Закавказским фронтом генерал армии И. В. Тюленев признавал, что в этом была «немалая доля вины командования и штаба Закавказского фронта, опрометчиво решивших, что перевалы сами по себе недоступны противнику. Лишь вмешательство Ставки исправило эту ошибку» [26, c. 324]. На перевалы были срочно выдвинуты подразделения 46 армии.

Советские солдаты, не имея необходимого снаряжения, вооружения, соответствующей экипировки, подготовки вели за перевалы ожесточённые бои в суровых зимних условиях, часто в летнем обмундировании, испытывая острую нужду в продовольствии и боеприпасах. 
Нередко ценою своей жизни они не позволили германским войскам проникнуть в Закавказье. О многих героических подвигах защитников перевалов советские люди узнали только через десятилетия, когда с потеплением вскрылись в горах ледники и обнажились тела погибших, вмёрзшие в лёд [7].

Немецкие альпинисты 49 корпуса 21 августа водрузили на Западном и Восточном Эльбрусе флаги нацистской Германии о чём с гордостью докладывал в Берлин командующий группой «А» фельдмаршал Лист. Но германское командование не придало этому значения, так как это не имело стратегического значения. Для него намного значимее было бы сообщение о выходе в Закавказье. Этот фракт широко использовался в пропаганде. Группа советских альпинистов сняла фрашистские фллаги 13 и 17 февраля, установив на обеих вершинах Эльбруса советские фрлаги [16, с. 198, 227].

Германское командование осенью 1942 г. явно не дооценило потенциальные возможности советских вооружённых сил. Так, Гитлер в директиве от 14 октября, говоря об успехах германских войск, достигнутых в ходе летних и осенних сражений, отмечал «русские в ходе последних боёв были серьёзно ослаблены и не смогут зимой 1942/1943 г. располагать такими же большими силами, какие имелись у них в прошлую зиму» [12, с. 328]. И, хотя немецкие войска на Кавказе ещё продолжали медленно наступать в районе городов Моздока, Нальчика, Новороссийска, но уже по всему было видно, что они выдыхаются. Ценой огромных усилий и потерь германским войскам удалось захватить г. Новороссийск и выйти к Чёрному морю. Но все попытки прорваться по побережью к г. Туапсе закончились провалом.

Преодолев сопротивление обессиленной 37-й армии, немецкие войска 25 октября захватили город Нальчик и начали наступление на г. Орджоникижзе, рассчитывая в ближайшее время выйти к г. Грозному. Достигнув предместий города, они взяли 7 ноября его предместье село Гизель. Но здесь немецкие воинские части столкнулись с мощным противодействием советских войск, ополчения, которые нанесли контрудар и 13 ноября освободили с. Гизель. Немецкие войска в этом районе были почти полностью окружены, поэтому вынуждены были отступать, чтобы не оказаться в котле. Таким образом, взять г. Орджоникижзе им не удалось. И немецкие войска больше здесь не наступали на Грозный, до которого было немногим более 100 км [17, с. 77-78]. 3а проявленные мужество и героизм, проявлен- ными личным составом в битве за Владикавказ, 6 воинских соединений были награждены орденами Красного Знамени.

В это время ожесточённые бои шли в горах Западного Кавказа против немецких войск, стремившихся прорваться к г. Туапсе и выйти на берег Чёрного моря с тем, чтобы нанести удар по его побережью в Закавказье. Но и здесь их постигла неудача. 20 декабря закончилась Туапсинская оборонительная операция войск Черноморской группы. Противник, пытавшийся прорваться здесь к Чёрному морю, понёс большие потери и перешёл к обороне. Таким образом, фронт здесь стабилизировался [3, с.142]. На этом по существу закончилась оборонительная операция советских войск на Северном Кавказе. Главным её итогом было то, что немецкие войска не смогли прорваться в Закавказье к жизненно важным экономическим центрам и было выиграно время для подготовки к контрнаступлению советских войск.

На Северном Кавказе началась активная подготовка к наступательным действиям для чего создались благоприятные условия в связи с начавшимся 19 ноября 1942 г. контрнаступлением советских войск под Сталинградом. Это вселило и в защитников Кавказа уверенность в скорой победе над врагом.

Советское командование разрабатывало планы контрнаступления войск на Северном Кавказе. Активизировались действия воинских соединений и партизан. Войска Закавказского фронта, получая подкрепления, готовились к наступательным боям. В декабре наносились контрудары, в ходе которых была освобождена часть оккупированной территории Северной Осетии, Кабардино-Балкарии, Чечено-Ингушетии.

В январе началось общее наступление войск Северной и Черноморской войсковых групп. 3 января был освобождён г. Моздок, 4 января г. Нальчик, 10-11 января города Кавказских Минеральных вод, 21 января Ставрополь, 12 февраля г. Краснодар. При этом Ставкой верховного главнокомандования ставилась задача не дать возможности немецким войскам отойти к Ростову, а окружить их на Северном Кавказе и разгромить [3, с. 216-217].

Немецкое командование, учитывая такой вариант, приняло меры по отводу 1-й танковой армии к Ростову, чтобы использовать её в боях за Донбасс. И значительной части немецких войск удалось отойти к Ростову до того, как он был освобождён войсками Южного фронта. Оставшиеся на Северном Кавказе немецкие войска отступили в западную часть Краснодарского края, уничтожая после себя всё, согласно 
приказу Гитлера. Они закрепились на глубоко эшелонированной, хорошо укреплённой оборонительной линии, построенной немцами с использованием населения и военнопленных, от Новороссийска до Азовского моря, включая Таманский полуостров, известной в истории, как «голубая линия». На ней немцы удерживали оборону более полугода, тем самым, прикрывая Крым и приковывая к себе войска Красной армии.

В историю вошли героические боевые действия десанта во время сражения за Новороссийск. Десант начали высаживать в районе Южной Озерейки и Станички 4 февраля 1943 года. Десантники героически сражались на небольшом клочке земли площадью 22 км², известном как «Малая земля» 225 дней, подвергаясь ожесточенным атакам противника с воздуха, моря и суши. В отдельные дни авиация производила до 2 тыс. самолётовылетов на плацдарм. Те, кто находился там, называли это ужасом. Вся земля была перепахана взрывами бомб, снарядов и мин. Казалось, что там не должно было остаться ничего живого. Но десантники мужественно сражались, приковывая к себе значительные силы противника. 21 защитник «Малой земли» был удостоен звания Героя Советского Союза, в их числе командир батальона морской пехоты майор Ц. Куников, командир дивизиона сторожевых катеров капитан 3-го ранга Н. Сипягин и др [11, с. 322].

Завершающим этапом битвы за Кавказ была Новороссийско-Таманская наступательная операция (10 сентября - 9 октября 1943 г.), проведённая Северо-Кавказским фронтом совместно с Черноморским флотом. К этому времени советские войска превосходили противника по пехоте и артиллерии в полтора раза, по авиации более чем в три раза, не уступали в танках [3, с. 283-286].

Немецкие воинские части ожесточённо оборонялись на хорошо подготовленной оборонительной линии. Но успешно развивавшееся наступление советских войск после поражения германской армии на Курской дуге вынудило Гитлера 4 сентября 1943 г. издать приказ о сдаче Кубанского плацдарма и отводе 17-й армии через Керченский пролив в Крым, чтобы высвободить соединения для решения других задач. В приказе подчёркивалось, что до наступления распутицы следовало всё эвакуировать с Кавказа в Крым, а то, что невозможно вывезти, полностью уничтожить «Противнику должна достаться на длительное время полностью не пригодная для использования и жилья пустыня, где на протяжении месяцев будут взрываться мины» [22, с. 526-527].
Прорвав «Голубую линию», преодолевая ожесточённо сопротивление противника, советские войска в трудных условиях продвигались вперёд. 9 октября 1943 года в 8 часов утра командующий 56-й армией генерал-лейтенант А. Гречко доложил Военному совету Северо-Кавказского фронта: «...Таманский полуостров частями 56-й армии к 7.009 октября 1943 года полностью очищен от немецких оккупантов» [11, с. 441]. С выходом частей Красной армии к Керченскому проливу Северный Кавказ был полностью очищен от немецких войск.

Таким образом, самая продолжительная битва Второй мировой войны закончилась поражением фашистских войск, которые, несмотря на прилагаемые усилия, не смогли прорваться в Закавказье. Германия так и не получила очень необходимую ей кавказскую нефть, что во многом предопределило её техническое поражение, так как техника при острой нехватке топлива не способна была выполнять в должной мере свои задачи.

Битва за Кавказ была проявлением массового героизма советских людей на фронте и в тылу. Десятки воинских соединений стали гвардейскими, были удостоены почётных наименований за особые отличия при освобождении населённых пунктов, территорий: Пятигорские, Краснодарские, Новороссийские, Таманские. Сотни тысяч воинов были награждены орденами и медалями, более 100 человек удостоены звания Героя Советского Союза. А лётчики А. И. Покрышкин и Д. Б. Глинка были дважды удостоены этого высокого звания за участие в воздушных боях на Кубани [20, с. 572, 21, C. 400$]$.

«Ночными ведьмами» прозвали фрашисты лётчиц 46-го, гвардейского, Таманского полка ночных бомбардировщиков 4-й воздушной армии, которым командовала майор Е. Бершанская. В этом полку за время войны 23 лётчицам было присвоено звание Героя Советского Союза из 28, удостоенных этого высокого звания в Военно-воздушных силах СССР за время войны. Ногаец Х. Кумуков из Карачаево-Черкесии, эстонец И. Лаар из Ставрополья, П. Гужвин, П. Бобрышев своими телами закрыли амбразуры пулемётов за что были удостоены звания Герой Советского Союза. За героизм в борьбе с противником на оккупированной территории звания Героя Советского Союза были удостоены два брата Евгений и Геня Игнатовы из партизанского отряда Краснодарского края, Александр Скоков, руководитель молодёжной подпольной организации села Величаевского Ставропольского края. 
Население территорий, освобождённых от оккупации, не доедая, не досыпая, надрываясь от непосильного труда, в труднейших прифронтовых условиях самоотверженно работало по восстановлению разрушенного оккупантами, стремясь оказать посильную помощь фронту и приблизить победу над врагом. Было продемонстрировано неразрывное единство фрронта и тыла.

Битва за Кавказ развеяла миф о противоречиях между советскими народами, продемонстрировала всему миру их единство, похоронила надежды германского руководства на развал многонационального советского государства с началом войны. Завершение битвы за Кавказ имело большое значение для насту- пательных действий Красной Армии на других фронтах.

Отдавая дань подвигу защитников Кавказа, Президиум Верховного Совета СССР 1 мая 1944 года учредил медаль «За оборону Кавказа», которой было награждено 864 тыс. человек, участвовавших в защите Кавказа [15, c.149-153].

Свидетельством увековечения подвига народов СССР при защите Кавказа в годы Великой Отечественной войны является присвоение почётных званий: «Город - герой» г. Новороссийску, «Город воинской славы» городам: Анапе, Владикавказу, Малгобеку, Нальчику, Туапсе [9; 10, с. 58-59; 30].

\section{Источники и литература}

1. Батыров У. Битва за Кавказ / У. Батыров, С. Гребенюк, В. Матвеев. М.; Владикавказ: Триада-фр, 2002. 411 с.

2. Битва за Кавказ: Военно-исторический очерк. М.: Воениздат, 1954.

3. Битва за Кавказ (1942-1943 гг.). М.: Триада, 2002. 428 с.

4. Внешняя политика Советского Союза в период Великой Отечественной войны. Т.1. М.: ОГИЗ, 1946. 698 с.

5. Вторая мировая война в воспоминаниях У. Черчилля, Ш. де Голля, К. Хэла, У. Леги, Д. Эйзенхауэра. М.: Политиздат», 1990. $558 \mathrm{c.}$

6. Государственный архив Ставропольского края. Ф. 1852. Оп.12. Д.33.

7. Гнеушев В. Г., Попутько А. Л. «Тайна Марухского ледника». Ставрополь: Кнмжное издательство, 1981. 560 с.

8. Говард. М. Большая стратегия / пер. с английского. М.: Воениздат, 1980. 464 с.

9. Города - герои Великой Отечественной войны. Атлас. М.: Главное управление геодезии и картографии при Совине СССР, 1988. 98 с.

10. Город воинской славы - сколько их в России? URL: http://fb.ru/article/145620/gorod-voinskoy-slavyi---skolko-ih-vrossii (Дата обращения: 28.05.2018).

11. Гречко А. А. Битва за Кавказ. М.: Воениздат, 1971. 416 с.

12. Дашичев В. И. Банкротство стратегии германского фашизма. Т. 2. М.: Наука, 1973. 664 с.

13. Ибрагимбейли. Х. Битва за Кавказ. Крах операции «Эдельвейс». М.: Вече, 2012. 416 с.

14. История Великой Отечественной войны Советского Союза. 1941-1945 гг. Т. 2. М.: Воениздат, 1961. 688 с.

15. Колесников Г. А., Рожков А. М. Ордена и медали СССР. М.: Воениздат, 1974. 269 с.

16. Кузнецов В. В. Горные стрелки Гитлера. «Эдельвейс в бою». М.: Яуза-пресс, 2008. 384 с.

17. Народный подвиг в битве за Кавказ. Сборник статей / ред. коллегия: А. В. Басов, Е. М. Зенин, Г. П. Иванов и др. М.: Наука, 1981. 373 с.

18. Пшеняник Г. А. Крах плана «Эдельвейс». Советская авиация в битве за Кавказ. 1942-1943. М.: Центрполиграфр, 2013. $380 \mathrm{c}$.

19. Ответный удар. Сборник статей. (К 40-летию освобождения Ставрополья от немецко-фрашистских захватчиков. Ставрополь: Книжное издательство, 1983. 223 с.

20. Советская военная энциклопедия. Т. 2. М.: Воениздат, 1978. 538 с.

21. Советская военная энциклопедия. Т. 6. М.: Воениздат, 1978. 671 с.

22. «Совершенно секретно! Только для командования». Стратегия фрашистской Германии в войне против СССР. Документы и материалы / Составитель полковник В И. Дашичев. М.: Наука, 1967. 752 с.

23.Сталинградская эпопея: Впервые публикуемые документы, рассекреченные ФСБ РФ: Воспоминания фельдмаршала Паулюса; Дневники и письма солдат РККА и вермахта; Агентурные донесения; Протоколы допросов; Докладные записки особых отделов фронтов и армий. М.: Звонница-МГ, 2000. 494 с.

24.Сталинград 1942-1943 гг.: Сталинградская битва в документах / А. А. Гуров и др. М., Калиниград, 1995. 421 с.

25.Тике В. Марш на Кавказ. Битва за нефть. 2942-1943. М.: Эксмо, 2005. 448 с.

26. Тюленев И. В. Через три войны. Воспоминания командующего Южным и Закавказским фронтами. 1941-1945 гг. М.: Центрполиграф, 2007. 399 с.

27. Януш С. В. Войсковые операции Советской армии в битве за Кавказ (1942-1943 гг.). Ставрополь: Книжное издательство, 2005. 576 с.

\section{References}

1. Batyrov U. Bitva za Kavkaz (Battle of the Caucasus). Moscow; Vladikavkaz: Triada-f, 2002. 411 p. (In Russian).

2. Bitva za Kavkaz: Voenno-istoricheskii ocherk (Battle of the Caucasus: Military and historical sketch). Moscow: Voenizdat, 1954. (In Russian).

3. Bitva za Kavkaz (1942-1943 gg.) (Battle of the Caucasus (1942-1943). Moscow: Triada, 2002. 428 p. (In Russian).

4. Vneshnyaya politika Sovetskogo Soyuza v period Velikoi Otechestvennoi voiny (Foreign policy of the Soviet Union in the period of the Great Patriotic War). Vol.1. M.: OGIZ, 1946. 698 p. (In Russian). 
5. Vtoraya mirovaya voina v vospominaniyakh U. Cherchillya, Sh. de Gollya, K. Khela, U. Legi, D. Eizenkhauera (World War II in W. Churchill's, Ch. de Gaulle's, K. Hal's, U. Legi's, D. Eisenhower's memoirs). Moscow: Politizdat», 1990. 558 p. (In Russian).

6. State Archive of Stavropol Krai. F.1852. Inv.12. D.33. (In Russian).

7. Gneushev V. G., Poput'ko A. L. Taina Marukhskogo lednika (Mystery of the Marukhsky glacier). Stavropol': Knmzhnoe izdatel'stvo, 1981. 560 p. (In Russian).

8. Govard M. Bol'shaya strategiya (Big strategy). Moscow: Voenizdat, 1980. 464 p. (In Russian).

9. Goroda - geroi Velikoi Otechestvennoi voiny. Atlas (Hero towns of the Great Patriotic War. Atlas). Moscow: Glavnoe upravlenie geodezii i kartografii pri Sovine SSSR, 1988. 98 p. (In Russian).

10. Gorod voinskoi slavy - skol'ko ikh v Rossii? (The city of military glory - how many them in Russia?) URL: http://fb.ru/ article/145620/gorod-voinskoy-slavyi---skolko-ih-v-rossii (Accessed: 28.05.2018). (In Russian).

11. Grechko A. A. Bitva za Kavkaz (Battle of the Caucasus). Moscow: Voenizdat, 1971. 416 p. (In Russian).

12. Dashichev V. I. Bankrotstvo strategii germanskogo fashizma (Bankruptcy of strategy of the German fascism). Vol. 2. Moscow: Nauka, 1973. 664 p. (In Russian).

13. Ibragimbeili. Kh. Bitva za Kavkaz. Krakh operatsii «Edel'veis» (Battle of the Caucasus. Crash of the operation "Edelweiss"). Moscow: Veche, 2012. 416 p. (In Russian).

14. Istoriya Velikoi Otechestvennoi voiny Sovetskogo Soyuza. 1941-1945 gg. (History of the Great Patriotic War of the Soviet Union. 1941-1945). Vol. 2. Moscow: Voenizdat, 1961. 688 p. (In Russian).

15. Kolesnikov G. A., Rozhkov A. M. Ordena i medali SSSR (Awards and medals of the USSR). Moscow: Voenizdat, 1974. 269 p. (In Russian).

16. Kuznetsov V. V. Gornye strelki Gitlera. «Edel'veis v boyu» (Hitler's mountain arrows. "Edelweiss in battle"). Moscow: Yauza-press, 2008. 384 p. (In Russian).

17. Narodnyi podvig v bitve za Kavkaz (A national feat in the battle of the Caucasus) / A. V. Basov, E. M Zenin, G. P. Ivanov etc. Moscow: Nauka, 1981. 373 p. (In Russian).

18. Pshenyanik G. A. Krakh plana «Edel'veis». Sovetskaya aviatsiya v bitve za Kavkaz. 1942-1943 (Plan crash "Edelweiss". The Soviet aircraft in the battle of the Caucasus. 1942-1943). Moscow: Tsentrpoligraf, 2013. 380 p. (In Russian).

19. Otvetnyi udar. Sbornik statei. (K 40-letiyu osvobozhdeniya Stavropol'ya ot nemetsko-fashistskikh zakhvatchikov) (Retaliation. Collection of articles. (To the 40 anniversary of liberation of the Stavropol Territory from fascist aggressors). Stavropol': Knizhnoe izdatel'stvo, 1983. 223 p. (In Russian).

20. Sovetskaya voennaya entsiklopediya (Soviet military encyclopedia). Vol. 2. Moscow: Voenizdat, 1978. 538 p. (In Russian).

21. Sovetskaya voennaya entsiklopediya (Soviet military encyclopedia). Vol. 6. Moscow: Voenizdat, 1978. 671 p. (In Russian).

22. "Sovershenno sekretno! Tol'ko dlya komandovaniya». Strategiya fashistskoi Germanii v voine protiv SSSR ("Top secret! Only for command". The strategy of fascist Germany in the war against the USSR). Dokuments and materials / composed by V I. Dashichev. Moscow: Nauka, 1967. 752 p. (In Russian).

23. Stalingradskaya epopeya: Vpervye publikuemye dokumenty, rassekrechennye FSB RF: Vospominaniya fel'dmarshala Paulyusa; Dnevniki i pis'ma soldat RKKA i vermakhta; Agenturnye doneseniya; Protokoly doprosov; Dokladnye zapiski osobykh otdelov frontov i armii (Stalingrad epic: For the first time the published documents declassified by FSB of the Russian Federation: Memoirs of the field marshal Paulyus; Diaries and letters of soldiers of RKKA and Wehrmacht; Secret-service reports; Protocols of interrogations; Reports of special departments of fronts and armies). Moscow: Zvonnitsa-MG, 2000. 494 p. (In Russian).

24. Stalingrad 1942-1943 gg.: Stalingradskaya bitva v dokumentakh (Stalingrad 1942-1943: The battle of Stalingrad in documents) / A. A. Gurov etc. Moscow, Kalinigrad, 1995. 421 p. (In Russian).

25. Tike V. Marsh na Kavkaz. Bitva za neft'. 1942-1943 (Marsh to the Caucasus. Fight for oil. 1942-1943). Moscow: Eksmo, 2005. 448 p. (In Russian).

26. Tyulenev I. V. Cherez tri voiny. Vospominaniya komanduyushchego Yuzhnym i Zakavkazskim frontami. 1941-1945 gg. (Through three wars. Memoirs of the commander of the South and the Transcaucasian fronts. 1941-1945). Moscow: Tsentrpoligraf, 2007. 399 p. (In Russian).

27. Yanush S. V. Voiskovye operatsii Sovetskoi armii v bitve za Kavkaz (1942-1943 gg.) (Army operations of the Soviet army in the battle of the Caucasus (1942-1943). Stavropol': Knizhnoe izdatel'stvo, 2005. 576 p. (In Russian). 